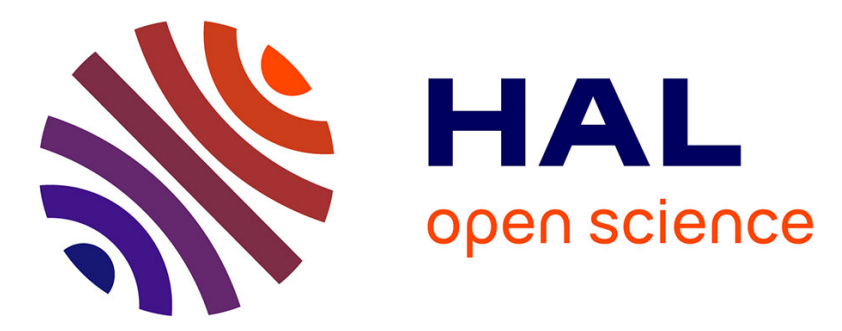

\title{
Singular physiological behavior of the scleractinian coral Porites astreoides in the dark phase
}

Pascal Claquin, Malika René-Trouillefou, Pascal Jean Lopez, Aurélien Japaud, Yolande Bouchon-Navaro, Sébastien Cordonnier, Claude Bouchon

\section{- To cite this version:}

Pascal Claquin, Malika René-Trouillefou, Pascal Jean Lopez, Aurélien Japaud, Yolande BouchonNavaro, et al.. Singular physiological behavior of the scleractinian coral Porites astreoides in the dark phase. Coral Reefs, 2021, 40 (1), pp.139-150. 10.1007/s00338-020-02023-4 . hal-03080724

\section{HAL Id: hal-03080724 https://hal.science/hal-03080724}

Submitted on 9 Feb 2021

HAL is a multi-disciplinary open access archive for the deposit and dissemination of scientific research documents, whether they are published or not. The documents may come from teaching and research institutions in France or abroad, or from public or private research centers.
L'archive ouverte pluridisciplinaire HAL, est destinée au dépôt et à la diffusion de documents scientifiques de niveau recherche, publiés ou non, émanant des établissements d'enseignement et de recherche français ou étrangers, des laboratoires publics ou privés. 
archives-ouvertes

\title{
Singular physiological behavior of the scleractinian coral Porites astreoides in the dark phase
}

\author{
Pascal Claquin, Malika Rene-Trouillefou, Pascal Lopez, Aurélien Japaud, \\ Yolande Bouchon-Navaro, Sébastien Cordonnier, Claude Bouchon
}

\section{To cite this version:}

Pascal Claquin, Malika Rene-Trouillefou, Pascal Lopez, Aurélien Japaud, Yolande Bouchon-Navaro, et al.. Singular physiological behavior of the scleractinian coral Porites astreoides in the dark phase. Coral Reefs, Springer Verlag, In press, 10.1007/s00338-020-02023-4 . hal-03080724

\section{HAL Id: hal-03080724 \\ https://hal.archives-ouvertes.fr/hal-03080724}

Submitted on 9 Feb 2021

HAL is a multi-disciplinary open access archive for the deposit and dissemination of scientific research documents, whether they are published or not. The documents may come from teaching and research institutions in France or abroad, or from public or private research centers.
L'archive ouverte pluridisciplinaire HAL, est destinée au dépôt et à la diffusion de documents scientifiques de niveau recherche, publiés ou non, émanant des établissements d'enseignement et de recherche français ou étrangers, des laboratoires publics ou privés. 


\title{
Singular physiological behavior of the scleractinian coral Porites astreoides in the dark phase
}

\author{
Pascal Claquin ${ }^{1,2}$ (1) Malika Rene-Trouillefou ${ }^{1,3}$ - Pascal Jean Lopez ${ }^{1}$. \\ Aurélien Japaud $^{1,3} \cdot$ Yolande Bouchon-Navaro $^{1,3} \cdot$ Sébastien Cordonnier $^{1,3}$. \\ Claude Bouchon ${ }^{1,3}$
}

Received: 17 March 2020/ Accepted: 24 October 2020

\begin{abstract}
Unlike most other corals that have been declining since the 1980s, the population of Porites astreoides, one of the dominant species of coral in Caribbean reefs, appears to be resilient. We investigated the physiological regulation of the electron transport chain of Symbiodiniaceae chloroplasts during the light/dark transition in $P$. astreoides compared to nine other common scleractinian corals. Protocols were applied to coral samples in seawater tanks and in situ. The maximum quantum yield $\left(F_{\mathrm{v}} / F_{\mathrm{m}}\right)$ in the dark and the effective photochemical efficiency $\left(F_{\mathrm{q}^{\prime}}\right.$ $\left.F_{\mathrm{m}^{\prime}}\right)$ in the light were measured during light-dark transitions, and alternative electron flow mechanisms were evaluated using fluorescence variation in response to serial irradiation pulses (SIP protocol). The variation in $F_{\mathrm{v}} / F_{\mathrm{m}}$ $\left(\Delta \mathrm{YII}_{\max }\right)$ was calculated after $3 \mathrm{~min}$ or $2 \mathrm{~h}$ of dark acclimation $\left(\Delta \mathrm{YII}_{\max (2 \mathrm{~h})} ; \Delta \mathrm{YII}_{\max (3 \mathrm{~min})}\right)$. The three
\end{abstract}

Topic Editor Simon Davy

Electronic supplementary material The online version of this article (https://doi.org/10.1007/s00338-020-02023-4) contains supplementary material, which is available to authorized users.

Pascal Claquin

pascal.claquin@unicaen.fr

1 Laboratoire de Biologie des ORganismes et Ecosystèmes Aquatiques (BOREA), FRE 2030, Muséum National d'Histoire Naturelle, CNRS, IRD, Sorbonne Université, Université de Caen Normandie, Université des Antilles, CP 26, 43 rue Cuvier, 75005 Paris, France

2 Centre de Recherches en Environnement Côtier (CREC) Station Marine, Université de Caen Normandie, Normandie Université, BP 49, 54, rue du Docteur Charcot, 14530 Luc-sur-Mer, France

3 Laboratoire d'Excellence "CORAIL", Université des Antilles, Pointe-à Pitre, Guadeloupe, France species that belong to the genus Porites ( $P$. astreoides, $P$. divaricata, $P$. furcata) showed plastoquinone reduction $(\mathrm{PQ})$ in response to the SIP protocol, unlike all the other

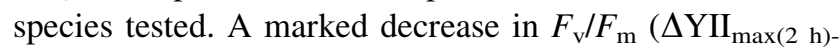
$=47.79 \%$ ) was observed in $P$. astreoides in the dark whereas the average $\Delta \mathrm{YII}_{\max (2 \mathrm{~h})}$ of the other species tested was $0.677 \%$. The decrease in $\Delta \mathrm{YII}_{\max }$ in P. astreoides was due to a significant increase in $F_{\mathrm{o}} \quad\left(\Delta F_{\mathrm{o}(2 \mathrm{~h})-}\right.$ $=-108.64 \% \pm \mathrm{SD} 21.48)$ whereas $F_{\mathrm{m}}$ remained relatively stable. The increase in $F_{\mathrm{o}}$ was attributed to reduction of the PQ pool through a chlororespiration-like mechanism known to reduce the production of reactive oxygen species. This mechanism was triggered immediately after exposure to the dark, while a brief and moderate light exposure reversed it. Given the ecological success of $P$. astreoides, we suggest that the high antioxidant capability of this species in the dark phase could be one of the factors favoring its survival in the face of various environmental and anthropogenic threats.

Keywords Chlororespiration-like · PAM - Caribbean reef corals $\cdot$ Resilience

\section{Introduction}

Alvarez-Filip et al. (2009) showed that the structural complexity of coral reefs in the Caribbean region has tended to decline since the 1970s. The massive corals, which also provide progressively less shelter for other reef organisms, could disappear in 10 to 15 yrs. Other analyses in the Caribbean Basin demonstrated that the reef coral cover has decreased by $80 \%$ over the last three decades, and by nearly $40 \%$ in the French Antilles in recent years (Gardner et al. 2003; Bouchon et al. 2004, 2008a, b). 
A fine examination of the dynamics of coral assemblages revealed a general decrease in the abundance of most species particularly of the species proposed to be the main builders of Caribbean reefs at the end of the last glaciation (i.e., Orbicella annularis, O. faveolata, Acropora palmata). In contrast, one species, Porites astreoides (Lamarck, 1816), which was among the dominant species of the Antillean coral assemblages from the early 1980s on, was seen to be more resistant than most other corals. For example, the coral cover in the Bay of the Grand Cul-deSac Marin in Guadeloupe Island (French Antilles) decreased from $42 \%$ in 1984 to $21 \%$ in 2018. In 1984, the two dominant species were Agaricia agaricites (9.9\%) and Porites astreoides (8.7\%), but in 2018, A. agaricites had dropped to $0.8 \%$, while $P$. astreoides remained dominant and accounted for $8 \%$ of the coral assemblage. In fact, Porites astreoides has maintained its original abundance and today is the dominant species in most Caribbean reefs (Green et al. 2008; Javier Gonzalez-Barrios and AlvarezFilip 2018). Porites astreoides was also shown to be resilient to experimental ocean acidification, to increases in temperature (Bove et al. 2019), and to one bleaching event (Levas et al. 2018), but appeared to be sensitive to successive heating events that can cause damage through bleaching (Grottoli et al. 2014; Schoepf et al. 2015).

One of the common features of reef scleractinian corals is that they harbor dinoflagellate algae belonging to the family Symbiodiniaceae (LaJeunesse et al. 2018). However, genera within this family may respond differently to environmental forcing factors (Franklin et al. 1996; Romaine et al. 1997; Robison and Warner 2006; Takahashi et al. 2009; Hennige et al. 2009; Ragni et al. 2010; Gregoire et al. 2017; Diaz-Almeyda et al. 2017). Under thermal and light stress reactive oxygen species (ROS) including superoxide $\left(\mathrm{O}_{2}{ }^{-}\right)$and singlet oxygen are produced in Symbiodiniaceae (Lesser 1996, 2006; Wooldridge and Done 2009; McGinty et al. 2012; Krueger et al. 2014) and can damage both the symbiotic Symbiodiniaceae and their hosts, and these two different organisms have developed specific mechanisms to mitigate the negative effects of these products (Krueger et al. 2014; Roberty et al. 2014; Rehman et al. 2016). Some mechanisms related to the transport of electrons in the photosynthetic apparatus have also been proposed (Roberty et al. 2014). Cyclic electron flow around photosystem I (PSI-CEF) and chlororespiration have been suggested to reduce ROS production in some Symbiodiniaceae genera hosted by scleractinian corals (Reynolds et al. 2008). These studies and many others explored whether photosynthesis and photoacclimation mechanisms are used to reduce the negative effects of high light intensity (Suggett et al. 2008; Roberty et al. 2014, 2015). However, oxidative stress has also been shown to occur in the dark, in the absence of photosynthetic activity (Tolleter et al. 2013; Gardner et al. 2017; Zhang et al. 2016; Diaz et al. 2016). Chlororespiration takes place in the dark or when the light intensity is very low. This mechanism is activated when the photosynthetic machinery is inoperative (Bennoun 1994; Nixon 2000) and, as mentioned above (Beardall et al. 2003), is known to reduce the production of damaging superoxide and hydroxyl radicals. The role of chlororespiration and which metabolic pathway is involved are still the subject of debate and many differences have been observed, for example between land plants and eukaryotic algae (Jans et al. 2008; Martin and Sabater 2010; Nawrocki et al. 2015). Several studies of Symbiodiniaceae reported a decrease in the maximum photochemical quantum yield of PSII $\left(F_{\mathrm{v}} / F_{\mathrm{m}}\right)$ at night or during prolonged dark periods that can be explained by a reduction in the PQ pool caused by a chlororespiration-like reaction (Jones and Hoegh-Guldberg 2001; Hill and Ralph 2008; Reynolds et al. 2008).

The aim of the present work was to compare the physiological regulation of the electron transport chain of Symbiodiniaceae during the dark phase of Porites astreoides with that in nine other species of scleractinian corals sampled on Caribbean reefs. We evaluated the level of plastoquinone $(\mathrm{PQ})$ reduction in these species and propose that it can be explained by a chlororespiration-like mechanism. We discuss the potential physiological and ecological benefits of such a mechanism.

\section{Materials and methods}

Measurements were made on 10 common species of Caribbean scleractinian corals: Acropora palmata, Agaricia agaricites, Orbicella annularis, O. faveolata, Porites astreoides, Porites divaricata, Porites furcata, Pseudodiploria clivosa, Pseudodiploria strigosa and Siderastrea siderea. PAM (Pulse Amplitude Modulated Fluorometer) measurements were performed between April 2016 and January 2019 in the Bay of the Grand Cul-de-Sac Marin $\left(16^{\circ} 21.651^{\prime} \mathrm{N} ; 61^{\circ} 34.787^{\prime} \mathrm{W}\right)$ in Guadeloupe Island (French Antilles). The morphometric characteristics of each species are listed in Table 1. Field measurements were performed at midday, and samples were collected between 9:00 a.m. and midday. Most field measurements were made, and samples were collected between a depth of 2 and $5 \mathrm{~m}$ (Table 1). Additional PAM measurements were made on Porites astreoides at depths of 10, 15 and $20 \mathrm{~m}$. Sampled colonies were placed in collection nets underwater. Upon surfacing, the corals were transferred to an insulated ice-box containing seawater collected at the sampling site and transported to the marine laboratory in less than 90 min. Each colony was placed in seawater tanks containing $20 \mathrm{~L}$ of seawater. 
Table 1 Colony form, calice distribution and size for each species, sampling depth and dates (month/year)

\begin{tabular}{|c|c|c|c|c|c|}
\hline Species & Colony form & Calice distribution & Calice size $(\mathrm{mm})$ & Depth (m) & Date \\
\hline Acropora palmata & Branching & Plocoid & $1.5-2.3$ & 1 & $04 / 16$ \\
\hline Agaricia agaricites & Massive & Meandroid & $2.0-3.0$ & $2-5$ & $01 / 19$ \\
\hline Orbicella annularis & Massive & Plocoid & $3.0-5.0$ & $2-5$ & $01 / 19$ \\
\hline Orbicella faveolata & Massive & Plocoid & $3.0-5.0$ & $2-5$ & $11 / 17$ \\
\hline Porites astreoides & Massive & Cerioid & $1.2-1.6$ & $2-5 ; 10 ; 15 ; 20$ & $11 / 17$ \\
\hline Porites divaricata & Branching & Cerioid & $0.9-1.2$ & $2-5$ & $11 / 17$ \\
\hline Porites furcata & Branching & Cerioid & $1.5-2.0$ & $2-5$ & $11 / 17$ \\
\hline Pseudodiploria clivosa & Flattened & Meandroid & $5.0-10.0$ & $2-5$ & $04 / 16$ \\
\hline Pseudodiploria strigosa & Massive & Meandroid & $6.0-9.0$ & $2-5$ & $04 / 16$ \\
\hline Siderastrea siderea & Massive & Cerioid & $4.0-5.0$ & $2-5$ & $11 / 17$ \\
\hline
\end{tabular}

\section{Measurements in the seawater tanks}

The water tanks were placed outside in the shade with air bubbling to avoid oxygen depletion, and the water was renewed at 12-h intervals. The temperature was maintained constant at the same temperature as that measured in the field (between 26.5 and $28.5^{\circ} \mathrm{C}$ depending on the sampling date). Natural light was monitored using a PAR underwater sensor LI-192 (Li-COR Biosciences, Lincoln, USA) and a Diving PAM-PAR sensor (Walz ${ }^{\mathrm{TM}}$, Effeltrich, Germany).

\section{Light-dark transition measurements}

In seawater tanks under natural light with a natural light cycle, PAM measurements were performed independently in triplicate for each species using an underwater Diving PAM (Walz ${ }^{\mathrm{TM}}$, Effeltrich, Germany) (Ralph et al. 1998). Light-dark transitions were measured starting on the sampling day and continued the following day. The coral sample was excited by a weak red measuring light $(1 \mu \mathrm{mol}$ photons $\mathrm{m}^{-2} \mathrm{~s}^{-1}, 650 \mathrm{~nm}$, frequency $0.6 \mathrm{kHz}$ ) to record minimum fluorescence $\left(F_{\mathrm{o}}\right)$. The optical fiber (diameter $6 \mathrm{~mm}$ ) of the PAM was positioned exactly $5 \mathrm{~mm}$ above the surface of the coral. The maximum fluorescence in the dark $\left(F_{\mathrm{m}}\right)$ or in the light $\left(F_{\mathrm{m}^{\prime}}\right)$ measured at 10 -min intervals was obtained using a multiple turnover flash method (Kromkamp and Forster 2003). We used a saturating white light pulse $\left(0.6 \mathrm{~s}, 4000 \mu \mathrm{mol}\right.$ photons $\left.\mathrm{m}^{-2} \mathrm{~s}^{-1}\right)$ produced by a halogen bulb that allowed reduction of the QA, QB and part of plastoquinone (PQ) pools. Blank fluorescence was done on a bleached coral skeleton under water on the sampling sites before measurements in order to remove the potential noise signal due to reflectance and the background fluorescence signal of seawater. The background fluorescence was always very low (lower than $2 \%$ of the $F_{\mathrm{o}}$ signal). The maximum quantum yield, $F_{\mathrm{v}} / F_{\mathrm{m}}$, was calculated according to the following equation (Genty et al. 1989):

$\frac{F_{\mathrm{v}}}{F_{\mathrm{m}}}=\frac{\left(F_{\mathrm{m}}-F_{\mathrm{o}}\right)}{F_{\mathrm{m}}}$

When measurements were made in the light, the effective quantum efficiency of PSII was computed as follows (Genty et al. 1989):

$\frac{F_{\mathrm{q}^{\prime}}}{F_{\mathrm{m}^{\prime}}}=\frac{\left(F_{\mathrm{m}^{\prime}}-F^{\prime}\right)}{F_{\mathrm{m}^{\prime}}}$

An index was calculated to estimate variation of the $F_{\mathrm{v}} /$ $F_{\mathrm{m}}$. The index corresponds to the percentage of the $F_{\mathrm{v}} / F_{\mathrm{m}}$ variation during the first $2 \mathrm{~h}$ of the dark period, where $\mathrm{DK}_{0}$ is the $F_{\mathrm{v}} / F_{\mathrm{m}}$ at the beginning of the dark phase (i.e., the first $F_{\mathrm{v}} / F_{\mathrm{m}}$ measurement after sunset when the PAR was below $1 \mu \mathrm{mol} \mathrm{m} \mathrm{s}^{-2}$ ), and $\mathrm{DK}_{2 \mathrm{~h}}$ is the $F_{\mathrm{v}} / F_{\mathrm{m}}$ after $2 \mathrm{~h}$ of darkness. An interval of $2 \mathrm{~h}$ was chosen because it corresponds to the average time needed to observe the lowest $F_{\mathrm{v}} / F_{\mathrm{m}}$ value in Porites astreoides during the dark period.

$\Delta \mathrm{YII}_{\max (2 \mathrm{~h})}=\left\{\frac{\left(\frac{F_{\mathrm{v}}}{F_{\mathrm{m}}}\right)_{\mathrm{DK}_{0}}-\left(\frac{F_{\mathrm{v}}}{F_{\mathrm{m}}}\right)_{\mathrm{DK}_{2 \mathrm{~h}}}}{\left(\frac{F_{\mathrm{v}}}{F_{\mathrm{m}}}\right)_{\mathrm{DK}_{0}}}\right\} \times 100$

The percentage variations of $F_{\mathrm{o}}$ and $F_{\mathrm{m}}$ called $\Delta F_{\mathrm{o}(2 \mathrm{~h})}$ and $\Delta F_{\mathrm{m}(2 \mathrm{~h})}$, respectively, were also calculated over a 2 -h dark period according to:

$\Delta F_{\mathrm{O} \text { or } \mathrm{m}(2 \mathrm{~h})}=\left\{\frac{\left(F_{\mathrm{o} \text { or } \mathrm{m}}\right)_{\mathrm{DK}_{0}}-\left(F_{\mathrm{o} \text { or } \mathrm{m}}\right)_{\mathrm{DK}_{2 \mathrm{~h}}}}{\left(F_{\mathrm{o} \text { or } \mathrm{m}}\right)_{\mathrm{DK}_{0}}}\right\} \times 100$

The morphometric (Table 1) and optical properties of the tissues of the 10 tested species differ and may partially influence PAM measurements (Enriquez et al. 2017; Wangpraseurt et al. 2019). In this study, the variations between light and dark transition were compared. Consequently, even if the saturating pulse was not able to saturate 
all the microalgae all through the layer of tissue of the corals, this would not influence the observed photobiology dynamics. In order to easily compare the $F, F_{\mathrm{o}}$ and $F_{\mathrm{m}^{\prime}}, F_{\mathrm{m}}$ dynamics, the values were normalized to the maximum value of $F_{\mathrm{m}}$. According to the manufacturer's recommendations, the range of raw fluorescence was 200 to 500 .

\section{Serial irradiance pulses (SIP) fluorescence response}

The serial irradiance pulses (SIP) fluorescence responses were recorded as proposed by Reynolds et al. (2008) to investigate the post-illumination behavior of the PQ pool. The SIP protocol was applied to the samples within $3 \mathrm{~h}$ of their arrival at the laboratory. Serial irradiance pulses (SIP) fluorescence responses were recorded independently in triplicate for each species. The same diving PAM as the one described above was used. The protocol was performed as follows: Scleractinian corals were acclimated to the dark for $1 \mathrm{~h}$. Base line fluorescence was monitored using a modulated weak red measuring light $(1 \mu \mathrm{mol}$ photons $\mathrm{m}^{-2} \mathrm{~s}^{-1}, 650 \mathrm{~nm}$, frequency $\left.0.6 \mathrm{kHz}\right)$, and $F_{\mathrm{m}}$ was measured by a 1 -s saturating flash $(650 \mathrm{~nm}, 4000 \mu \mathrm{mol}$ photons $\mathrm{m}^{-2} \mathrm{~s}^{-1}$ ) at $30 \mathrm{~s}$ intervals. The minimum fluorescence measured after a saturating flash corresponds to $F_{\mathrm{o}^{\prime}}$. An increase of $F_{\mathrm{o}^{\prime}}$ after the flash reveals a post-illumination PQ pool reduction (Reynolds et al. 2008; Roberty et al. 2014) while a stability of $F_{\mathrm{o}^{\prime}}$ indicates sustained linear electron transport activities between PSII and PSI.

\section{Field measurements}

Measurements were made using the same setup as described above in three independent colonies. The scleractinian corals were placed in the dark for $F_{\mathrm{v}} / F_{\mathrm{m}}$ measurements using a simple homemade experimental device comprising a black rubber swimming cap with the PAM Fiber optic cable running through it. The swimming cap covered the coral and ensured it was completely in the dark without damaging it.

A field index was calculated to estimate variations of the $F_{\mathrm{v}} / F_{\mathrm{m}}$. The index corresponds to the percentage of the $F_{\mathrm{v}} /$ $F_{\mathrm{m}}$ variation during the first $3 \mathrm{~min}$ of the dark period, $\mathrm{DK}_{0}$ being the $F_{\mathrm{v}} / F_{\mathrm{m}}$ at the beginning of the dark phase and $\mathrm{DK}_{3}$ min the $F_{\mathrm{v}} / F_{\mathrm{m}}$ after 3 min of dark. A 3-min interval was chosen because of scuba diving constraints and because a significant decrease of $F_{\mathrm{v}} / F_{\mathrm{m}}$ was already observed in Porites astreoides within this short dark period.

$\Delta \mathrm{YII}_{\max (3 \min )}=\left\{\frac{\left(\frac{F_{\mathrm{v}}}{F_{\mathrm{m}}}\right)_{\mathrm{DK}_{0}}-\left(\frac{F_{\mathrm{v}}}{F_{\mathrm{m}}}\right)_{\mathrm{DK}_{3 \min }}}{\left(\frac{F_{\mathrm{v}}}{F_{\mathrm{m}}}\right)_{\mathrm{DK}_{0}}}\right\} \times 100$

\section{Data analyses}

Analyses of variance (ANOVA) were followed by pairwise multiple comparison (Tukey's test). Previously, a Kolmogorov-Smirnov normality test and an equal variance (homoscedasticity) test were applied. Differences were considered significant when the $p$ value was less than 0.05 . When ANOVA could not be performed, a Kruskal-Wallis one-way analysis of variance by ranks test was applied. All the plots were produced using SigmaPlot 12.5 (Systat Software Inc. Chicago, USA).

\section{Results}

$F_{\mathrm{o}}$ and $F_{\mathrm{m}}\left(\right.$ or $F_{\mathrm{q}^{\prime}}$ ) measured on Porites astreoides and Pseudodiploria strigosa displayed very different dynamics during the light/dark transitions and during the night (Fig. 1). In Porites astreoides, in the dark, $F_{\mathrm{o}}$ increased significantly from 31.50 to 58.65 (slope test $p<0.001$ ) whereas in Pseudodiploria strigosa, it decreased significantly from 34.68 to 28.65 (slope test $p=0.01$ ). A decrease in $F_{\mathrm{o}}$ in the dark was also observed in the seven other species tested: Acropora palmata, Agaricia agaricites, Orbicella annularis, O. faveolata, Porites furcata, Pseudodiploria clivosa, and Siderastrea siderea. Interestingly, Porites divaricata showed an increase in $F_{\mathrm{o}}$ but the magnitude was much lower than in Porites astreoides (Supplementary Fig. 1). At the end of the light period, during the light dark transition, Pseudodiploria strigosa showed an increase in $F_{\mathrm{q}^{\prime}} / F_{\mathrm{m}^{\prime}}$ from 0.632 up to a maximum 0.661 , which was reached during the dark phase $\left(F_{\mathrm{v}} / F_{\mathrm{m}}\right)$. This increase in $F_{\mathrm{q}^{\prime}} / F_{\mathrm{m}^{\prime}}$ was due to a decrease in fluorescence $(F)$ in the dark associated with a weak decrease in $F_{\mathrm{m}^{\prime}}$ and $F_{\mathrm{m}}$. In contrast, in Porites astreoides, $F_{\mathrm{v}} / F_{\mathrm{m}}$ dropped from 0.642 to reach a minimum 0.271 within $2 \mathrm{~h}$ after the night phase. This drop was mainly due to the increase in $F_{\mathrm{o}}$. The light-dark transition was performed under natural light and with a natural light cycle, but the same results were observed when the samples were placed in the dark during the daylight period.

Based on these observations, an index was built to estimate $F_{\mathrm{v}} / F_{\mathrm{m}}$ dynamics. The $\Delta \mathrm{YII}_{\max (2 \mathrm{~h})}$ highlights the singular behavior of Porites astreoides sampled in shallow water that showed a mean value of $47.79 \%$ while the average of the nine other species tested was $0.677 \%$ (Fig. 2). The mean $\Delta \mathrm{YII}_{\max (2 \mathrm{~h})}$ value of the two other Porites was $3.29 \%$ and $-1.15 \%$ for $P$. divaricata and $P$. furcata, respectively. The mean $\Delta \mathrm{YII}_{\max (2 \mathrm{~h})}$ value of Porites astreoides differed significantly $\left(F_{(1,29)}=63.665\right.$, $p<0.001$, Tukey's test $p<0.001$ ) from the other species tested, whereas no significant differences were observed among the nine other species. 

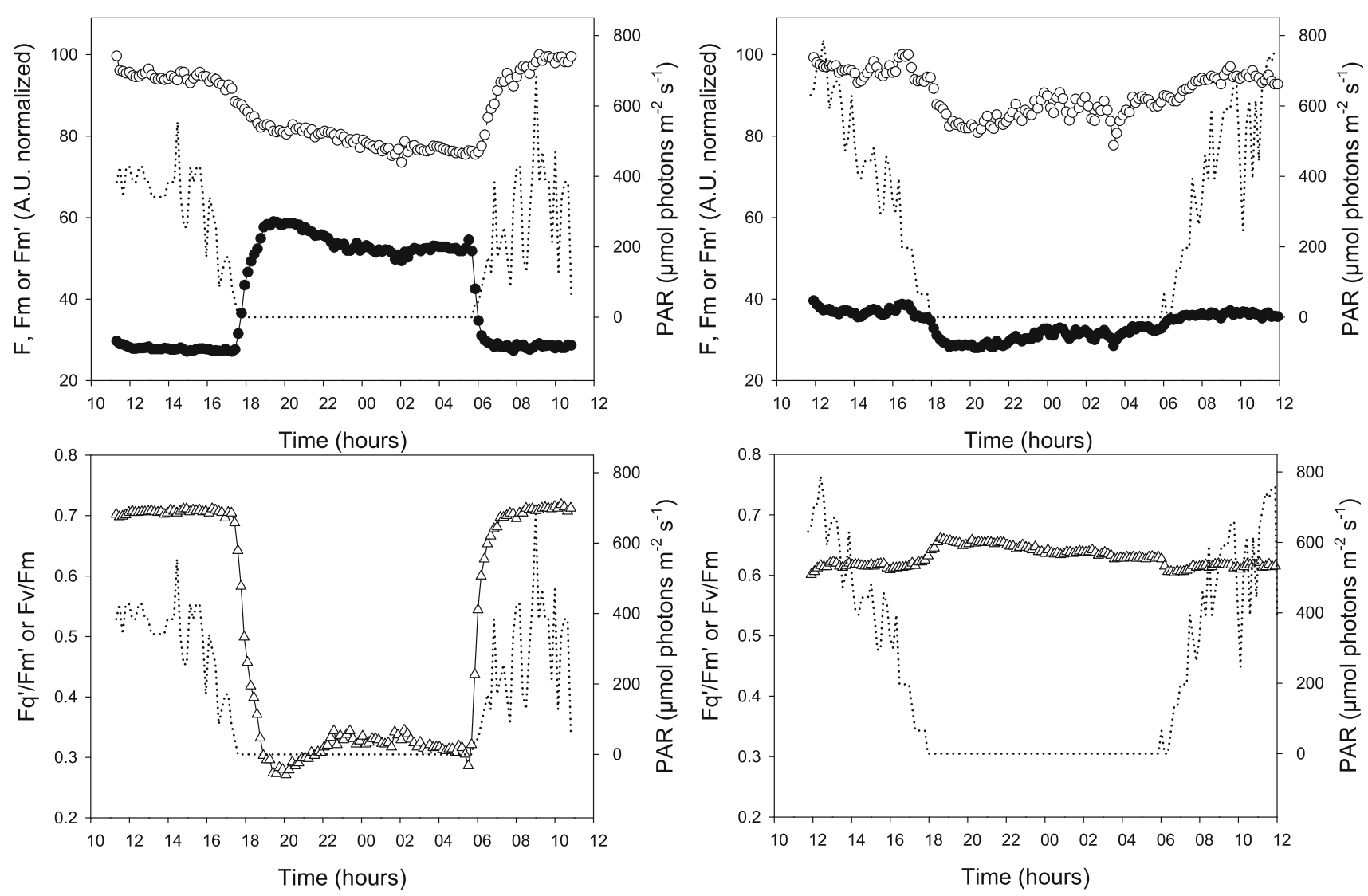

a Porites astreoides

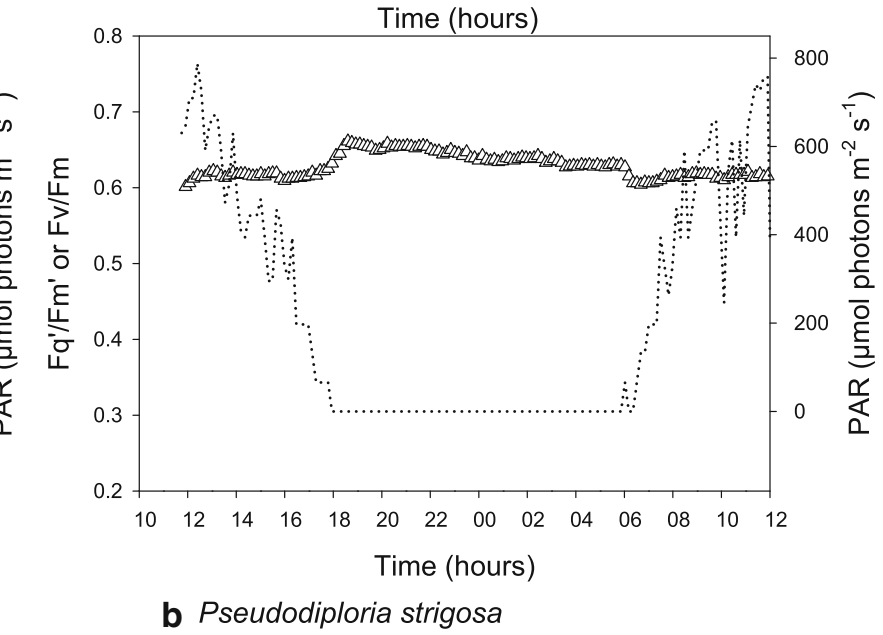

Fig. 1 Dynamics of $F$ (black circle), $F_{\mathrm{m}}$ or $F_{\mathrm{m}^{\prime}}$ (white circle) and of $F_{\mathrm{v}} / F_{\mathrm{m}}$ or $F_{\mathrm{q}^{\prime}} / F_{\mathrm{m}^{\prime}}$ (white triangle) in one sample of Porites astreoides (a) and in one sample of Pseudodiploria strigosa (b) during light dark transitions (dotted line: PAR)

The mean $\Delta F_{\mathrm{o}(2 \mathrm{~h})}$ values of all the species were higher than zero, except Porites astreoides in which a major significant increase in $F_{\mathrm{o}}$ occurred during the night (Fig. 3). The increase in $F_{\mathrm{o}}$ during the night led to a very high negative value of $\Delta F_{\mathrm{o}(2 \mathrm{~h})}(-108.64 \% \pm \mathrm{SD} 21.48)$ significantly different from all other species $\left(F_{(1,29)}=28.788\right.$, $p<0.001$, Tukey's test $p<0.001)$. In contrast, Agaricia agaricites and Porites furcata presented high positive values of, respectively, $\Delta F_{\mathrm{o}(2 \mathrm{~h})}(21.22 \% \pm \mathrm{SD} 19.81)$ and $\left(19.09 \% \pm\right.$ SD 15.58), indicating a marked decrease in $F_{\mathrm{o}}$ during the dark phase, but these species displayed high variability. $F_{\mathrm{m}}$ remained more stable than $F_{\mathrm{o}}$ even in Porites astreoides. $\Delta F_{\mathrm{m}(2 \mathrm{~h})}$ was positive in all species and ranged between $5.01 \%$ (Orbicella faveolata) and $21.40 \%$ (Agaricia agaricites), indicating a decrease in $F_{\mathrm{m}}$ after $2 \mathrm{~h}$ of adaptation to the dark. No significant differences were observed in the relationship between the species tested (KW: $\chi^{2}=6.110, d f=9, p=0.729$ ). This result highlights the fact that the $\Delta \mathrm{YII}_{\max (2 \mathrm{~h})}$ dynamics is mainly controlled by the $F_{\mathrm{o}}$ dynamics in Porites astreoides.
In order to confirm a reduction of the quinone pool of the PSII during the night, Porites astreoides was exposed to a moderate light source $\left(150 \mu \mathrm{mol}\right.$ photons $\left.\mathrm{m}^{-2} \mathrm{~s}^{-1}\right)$ for $1 \mathrm{~min}$, at two periods in the night before the PAM saturating flashes were produced ( $F_{\mathrm{m}}$ measurement) (Fig. 4). An increase in $F_{\mathrm{v}} / F_{\mathrm{m}}$ from 0.08 to 0.52 was observed in the first light period, and from 0.09 to 0.61 in the second light period. These increases were mainly due to the decrease in $F_{\mathrm{o}}$ as described above. Then, in the dark, following these two short light periods, $F_{\mathrm{v}} / F_{\mathrm{m}}$ dropped to previous values. At the end of the night $F_{\mathrm{q}^{\prime}} / F_{\mathrm{m}^{\prime}}$ increased on exposure to sunlight and reached 0.69 at 7:45 a.m. (Fig. 4).

The $\Delta \mathrm{YII}_{\max (3 \mathrm{~min})}$ measured in situ (Fig. 5) was in agreement with the trends observed in $\Delta \mathrm{YII}_{\max (2 \mathrm{~h})}$

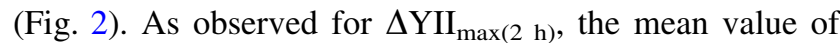
$\Delta \mathrm{YII}_{\max (3 \mathrm{~min})}$ of Porites astreoides was significantly higher than all the other species $\left(F_{(1,29)}=32.472\right.$, $p<0.001$, Tukey's test $p<0.001$ ). In all the species tested, except Acropora palmata (3.56\% \pm SD 3.30) and Porites furcata $(2.59 \% \pm \mathrm{SD} 1.53)$, the $\Delta \mathrm{YII}_{\max (3 \mathrm{~min})}$ was

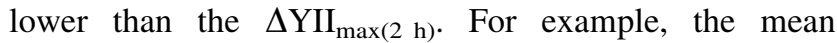




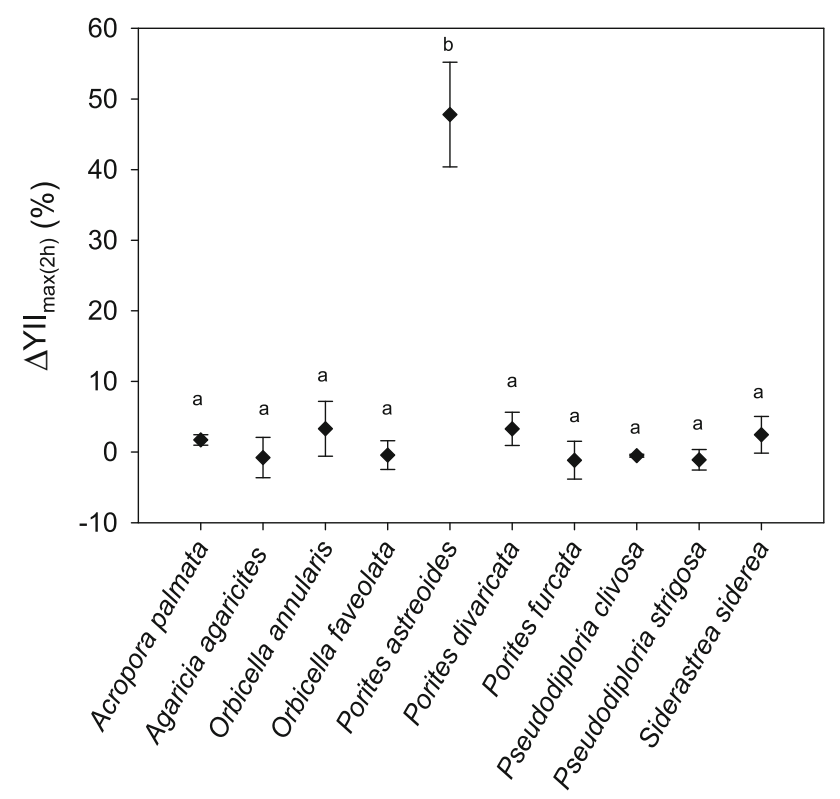

Fig. $2 \Delta \mathrm{YII}_{\max (2 \mathrm{~h})}(\%)$ corresponding to the percentage of $F_{\mathrm{v}} / F_{\mathrm{m}}$ variation during the first $2 \mathrm{~h}$ of the dark period, measured in triplicate (mean $\pm \mathrm{SD}$ ) in 10 species of Caribbean scleractinian corals. Data were obtained from samples collected at a depth of 1 to $5 \mathrm{~m}$. Different lowercase letters indicate significantly different means $(p<0.05)$

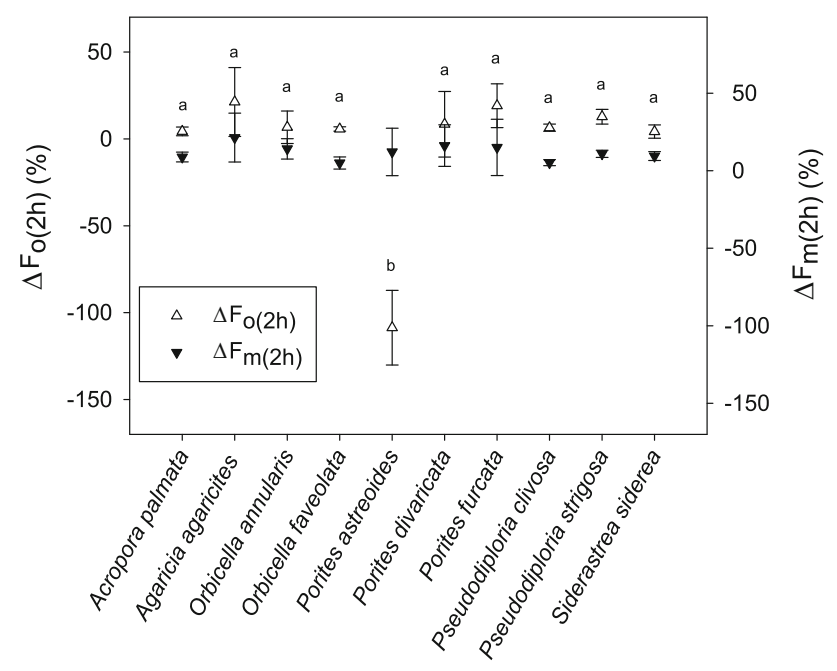

Fig. $3 \Delta F_{\mathrm{o}(2 \mathrm{~h})}(\%)$ and $\Delta F_{\mathrm{m}(2 \mathrm{~h})}(\%)$ measured in triplicate in 10 species of Caribbean scleractinian corals after $2 \mathrm{~h}$ in the dark (mean $\pm \mathrm{SD}$ ). Data were obtained on samples taken collected at a depth of 1 to $5 \mathrm{~m}$. Different lowercase letters indicate significantly different means $(p<0.05)$ between $\Delta F_{\mathrm{o}(2 \mathrm{~h})}(\%)$ values

$\Delta \mathrm{YII}_{\max (3 \mathrm{~min})}$ value of Porites astreoides was $32.22 \%$, which corresponds to a decrease of 15.57 between $\Delta \mathrm{YII}_{\max (2 \mathrm{~h})}$ and $\Delta \mathrm{YII}_{\max (3 \mathrm{~min})}$. In all the other species, the average decrease between the two $\Delta \mathrm{YII}_{\max }$ calculated was 4.54. Except for the three species of the Porites genus and Acropora palmata, the other tested species had a negative $\Delta \mathrm{YII}_{\max (3 \mathrm{~min})}$. Agaricia agaricites, presented the lowest mean value of $\Delta \mathrm{YII}_{\max (3 \mathrm{~min})}(-23.62 \% \pm \mathrm{SD} 6.51)$

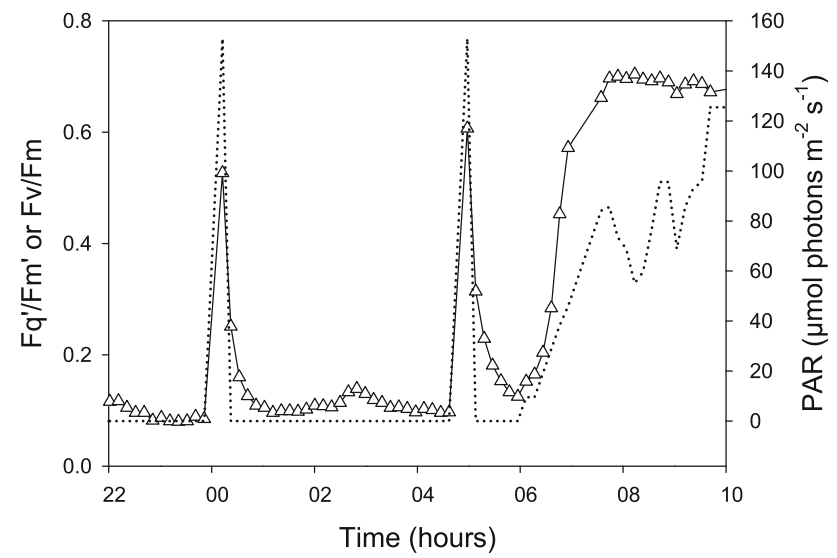

Fig. 4 Effects of a short light phase during the dark period on $F_{\mathrm{v}} / F_{\mathrm{m}}$ in one sample of Porites astreoides. (Dotted line: PAR)

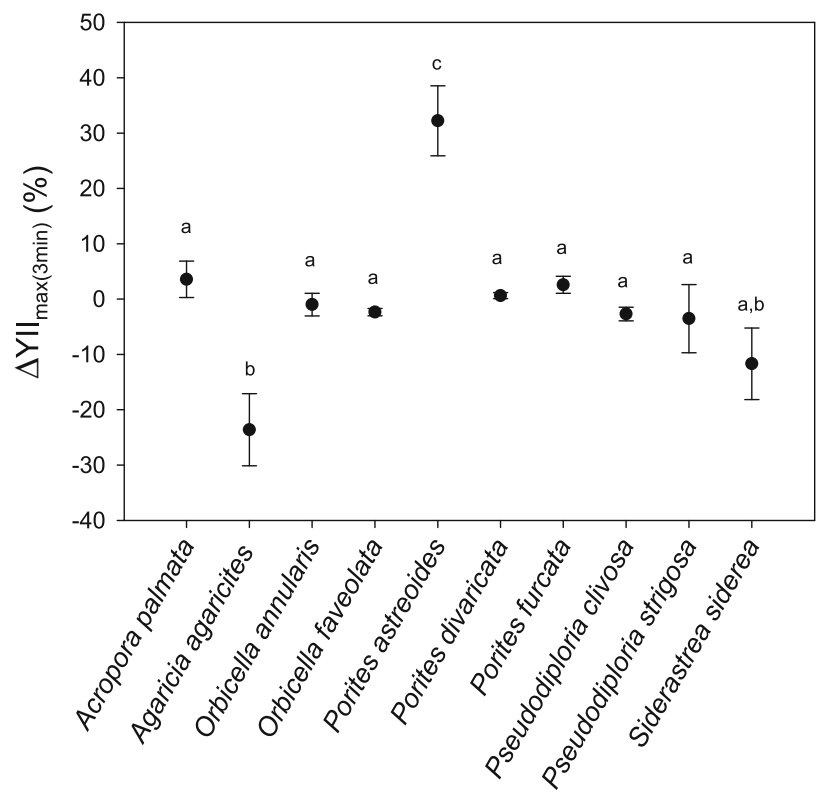

Fig. $5 \Delta \mathrm{YII}_{\max (3 \mathrm{~min})}(\%)$ corresponding to the percentage of $F_{\mathrm{v}} / F_{\mathrm{m}}$ variation during the first $3 \mathrm{~min}$ of the dark period, measured in triplicate $($ mean $\pm \mathrm{SD})$ in 10 species of Caribbean scleractinian corals. Data come from samples collected at a depth of 1 to $5 \mathrm{~m}$. Different lowercase letters indicate significantly different means $(p<0.05)$

which differed significantly from that in all the other species $\left(F_{(1,29)}=32.472, p<0.001\right.$, Tukey's test $\left.p<0.001\right)$ except $S$. siderea $(-11.70 \% \pm \mathrm{SD}$ 6.47) (Tukey's test $p=0.064)$.

Because Porites astreoides showed a particular physiological behavior in shallow water, additional measurements were made at other depths. $\Delta \mathrm{YII}_{\max (3 \mathrm{~min})}$ of Porites astreoides was measured in situ at four different depths, 4 , 10, 15 and $20 \mathrm{~m}$ (Fig. 6). The mean coefficient of light extinction (Kpar) in the sampling area was $0.07 \mathrm{~m}^{-1}$. No significant differences between $\Delta \mathrm{YII}_{\max (3 \mathrm{~min})}$ values were observed as a function of depth $\left(F_{(1,11)}=0.234\right.$, 


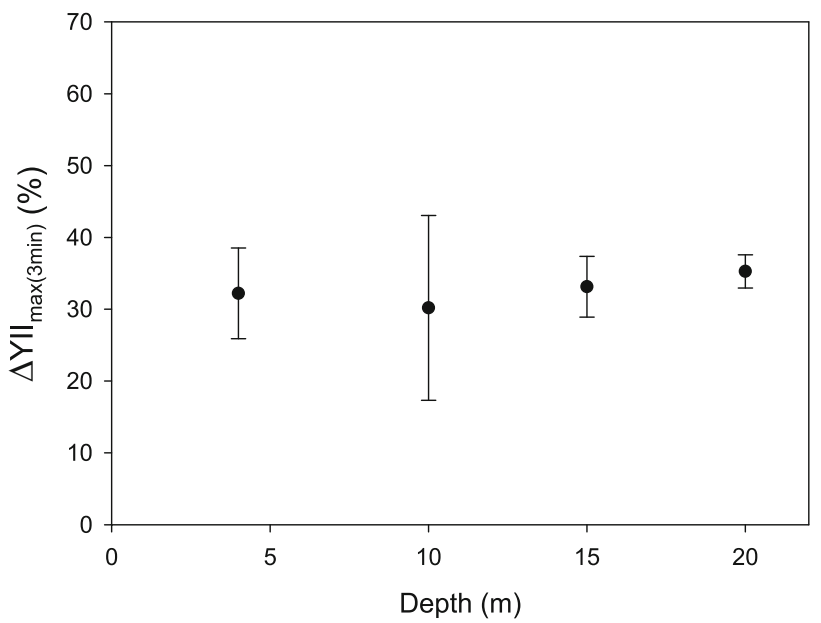

Fig. $6 \Delta \mathrm{YII}_{\max (3 \mathrm{~min})}(\%)$ corresponding to the percentage variation in $F_{\mathrm{v}} / F_{\mathrm{m}}$ during the first 3 min of the dark period, measured in situ in triplicate on Porites astreoides at four different depths (4, 10, 15, $20 \mathrm{~m})($ mean $\pm \mathrm{SD})$

$p=0.870)$. Considering all depths, the mean value of $\Delta \mathrm{YII}_{\max (3 \mathrm{~min})}$ was $32.71 \% \pm \mathrm{SD} 6.72$.

The SIP protocol was applied to the dark adapted scleractinian corals selected in this work. We observed two types of responses (Fig. 7). After activation of the measuring light that led to the first increase in fluorescence in Porites astreoides, we observed a progressive increase in $F_{\mathrm{o}^{\prime}}$ that can be attributed to a reduction of the plastoquinone pool. More precisely, after the second saturating flash, a light-induced plastoquinone oxidation is observed leading to a decrease of $F_{\mathrm{o}^{\prime}}$ just after the flash, which was immediately followed by an increase of $F_{\mathrm{o}^{\prime}}$ due to PQ dark reduction. Conversely, in Pseudodiploria strigosa, after the first increase in fluorescence due to measuring light, $F_{\mathrm{o}^{\prime}}$ remained stable, pointing to an equilibrium between reduction and oxidation of the plastoquinone pool due to linear electron transport between PSII and PSI. We then classified the two kinds of response of PQ-reduction SIP response as "positive" or "neutral" (Table 2). The three species of Porites tested displayed AEF activity while all the other species tested showed a similar pattern to that of Pseudodiploria strigosa, indicating no PQ-reduction. A positive PQ-reduction SIT response was measured in Porites astreoides at depths of 4, 10, 15 and $20 \mathrm{~m}$. The decrease in maximum fluorescence observed after several flashes for both types of SIP responses, can be attributed to non-phototochemical quenching regulations.

\section{Discussion}

In the present study, various protocols were applied dealing with the physiological regulations of the electron transport chain of coral-associated Symbiodiniaceae with a focus on the light/dark transition. Measurements were made in situ and in freshly sampled corals placed in regulated seawater tanks, and no difference was observed between the two, indicating that mechanisms explored here were not affected by perturbations resulting from handling. The in situ protocols enabled wide screening of the physiological behavior of corals without being obliged to collect them, while the laboratory protocols allowed us to explore physiological mechanisms in more detail.

An archetypal behavior of the maximum photochemical quantum yield during the dark phase consists of an increase in this parameter, due to a decrease in $F_{\text {o }}$ caused by oxidation of the PQ pool (Genty et al. 1989). In the present study, this behavior was observed in all the species tested except in Porites astreoides. In this species, the main result of our experiments was the marked variation in the maximum photochemical quantum yield after only a few minutes of dark exposure. The marked decrease in $F_{\mathrm{v}} / F_{\mathrm{m}}$ was mainly due to the increase in $F_{\mathrm{o}}$ in the dark phase (Fig. 1), while $F_{\mathrm{m}}$ remained relatively stable.

There is only a limited literature on the subject of PSII fluorescence in coral during the dark period. In a previous work on three species of coral, Acropora millepora, Pocillopora damicornis and Pavona decussata from the Great Barrier Reef in Australia (Hill et al. 2012), it was shown that $F_{\mathrm{v}} / F_{\mathrm{m}}$ display archetypal behavior, as we observed in nine of the coral species we tested. In another study on Porites astreoides in Belize (Caribbean Sea), Warner et al. (2006) observed no reduction in $F_{\mathrm{v}} / F_{\mathrm{m}}$ in the dark phase. These authors mentioned that their measurements were made in the early morning close to sunrise, but in a preliminary work cited in the article, they did not report any differences between morning $F_{\mathrm{v}} / F_{\mathrm{m}}$ values and those recorded approximately $1 \mathrm{~h}$ after sunset. The data we obtained from the same species showed that $F_{\mathrm{v}} / F_{\mathrm{m}}$ increased at the beginning of sunset and that very low light led to a decrease in $F_{\mathrm{o}}$ due to rapid re-oxidation of the PQ pool (Fig. 1). Warner et al. (2006) probably did not observe the mechanism we observed because it disappears at very low light (below $10 \mu \mathrm{mol}$ photons $\mathrm{m}^{-2} \mathrm{~s}^{-1}$ ) and is therefore already suppressed by sunrise. Another possible explanation for the apparent discrepancy between the two studies is the diversity within the Symbiodiniaceae complex. Several lineages of Symbiodiniaceae may be present in the host and may differ depending on environmental conditions, including depth (Rowan and Knowlton 1995; Iglesias-Prieto et al. 2004; Reynolds et al. 2008; 
Fig. 7 Examples of CEP-SIP responses in a sample of Porites astreoides (a) and in a sample of Pseudodiploria strigosa (b)
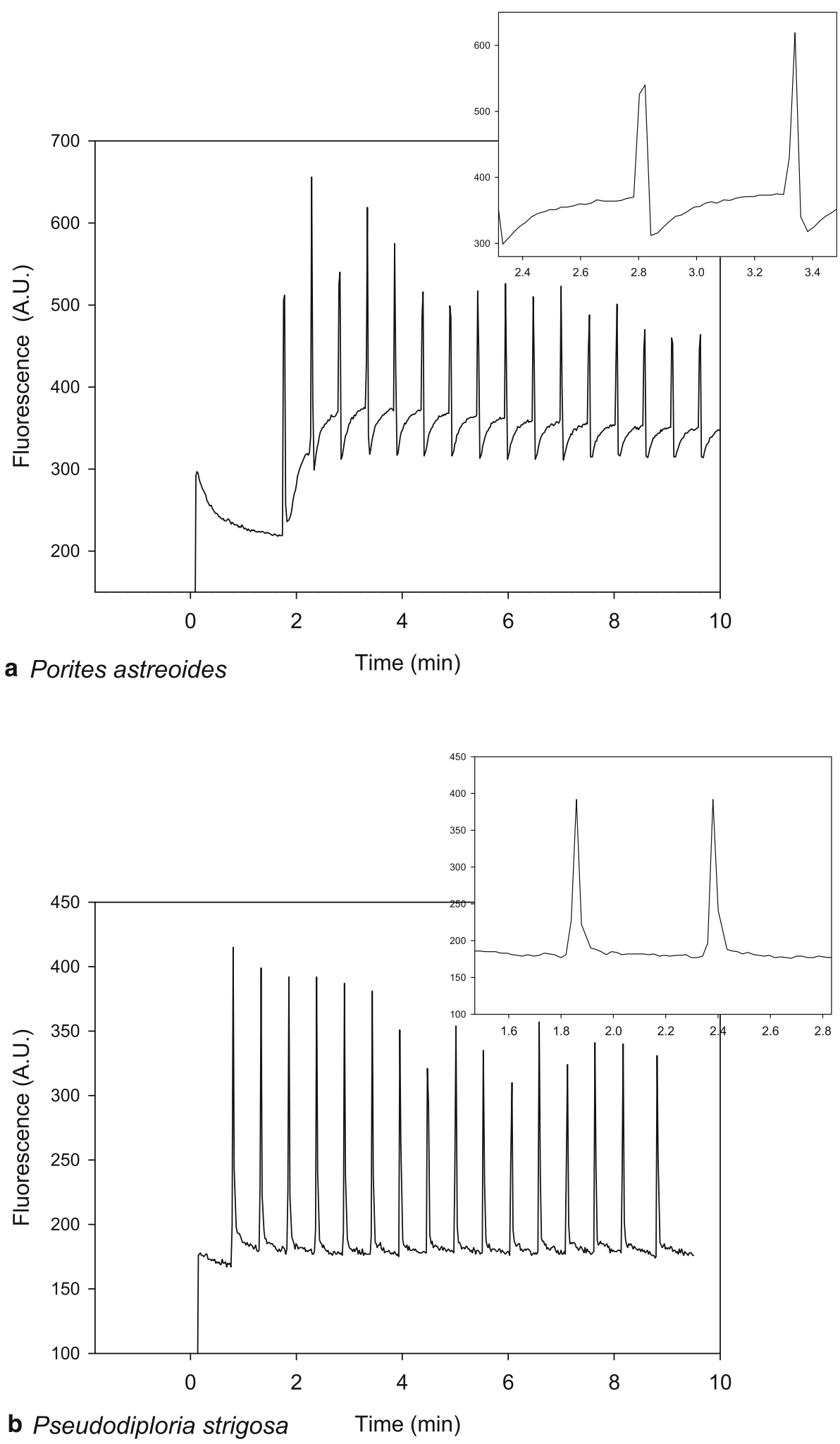

LaJeunesse et al. 2010; Byler et al. 2013; Pochon et al. 2015). Nevertheless, several authors showed that the Symbiodiniaceae associated with Porites astreoides in the Caribbean Sea are quite homogenous in shallow water and are mainly represented by Symbiodinium ITS2 type A4 (Reynolds et al. 2008; Hauff et al. 2016). The homogeneity of the response we observed in $P$. astreoides suggests that the same Symbiodinium symbiont occurs in shallow waters 
Table 2 PQ-reduction-SIP responses in 10 species of Caribbean scleractinian corals

\begin{tabular}{ll}
\hline Species & PQ-reduction SIP response \\
\hline Acropora palmata & Neutral \\
Agaricia agaricites & Neutral \\
Orbicella annularis & Neutral \\
Orbicella faveolata & Neutral \\
Porites astreoides $(2-5 \mathrm{~m})$ & Positive \\
Porites astreoides $(10 \mathrm{~m})$ & Positive \\
Porites astreoides $(15 \mathrm{~m})$ & Positive \\
Porites astreoides $(20 \mathrm{~m})$ & Positive \\
Porites divaricata & Positive \\
Porites furcata & Positive \\
Pseudodiploria clivosa & Neutral \\
Pseudodiploria strigosa & Neutral \\
Siderastrea siderea & Neutral \\
\hline
\end{tabular}

and down to a depth of $20 \mathrm{~m}$ (Fig. 6). The complementary molecular analyses performed during the course of the present study demonstrated the presence of Symbiodinium ITS2 type A4 in our samples (Japaud 2017). ITS2 type A4 is commonly reported in symbiotic association with Porites astreoides and is considered to belong to the "shallow water specialist" lineage of Symbiodiniaceae (Rowan and Knowlton 1995; LaJeunesse 2002; Serrano et al. 2016).

The increase in $F_{\mathrm{o}}$ in the dark phase we measured can be attributed to the reduction of the PQ pool, which is typical of chlororespiration-like mechanisms, as already reported in isolated Symbiodiniaceae lineages in culture, and in coral samples (Jones and Hoegh-Guldberg 2001; Hill and Ralph 2008; Reynolds et al. 2008). To evaluate the proposed chlororespiration-like mechanism in the Caribbean coral species, we propose two simple indexes, $\Delta \mathrm{YII}_{\max (2 \mathrm{~h})}$ and $\Delta \mathrm{YII}_{\max (3 \mathrm{~min})}$. Both indexes highlight the particular PQ dynamics of Porites astreoides in the dark with a very high value of $\Delta \mathrm{YII}_{\max }$. We assume these indexes can be used as indicators of chlororespiration-like mechanisms. We observed that the chlororespiration-like mechanism was triggered immediately after exposure to the dark, it appears to be independent of any circadian clock, and brief exposure to light can interrupt it (Fig. 4). Chlororespiration is due to the oxidation of carbon reserves, with oxygen as a terminal electron acceptor using photosynthetic electron transfer chain by sharing plastoquinone and some stromal electron carriers (NADPH dehydrogenase, cytochrome $b_{6}$ $f$ complex, terminal oxidase (PTOX)) (Nawrocki et al. 2019). This process, which behaves like an antagonist of the light reactions of the photosynthesis by consuming $\mathrm{O}_{2}$ and NADPH, is preserved in most photosynthetic lineages (Nawrocki et al. 2015).
Different enzymes are involved in chlororespiration in higher plants and algae, and two types of enzymes play a major role. The first, the NAD(P)H:PQ oxidoreductase presents two forms, called type I NADH dehydrogenase (NDH-1) and type II NADH dehydrogenase (NDH-2), that reduce $\mathrm{PQ}$. NDH-2, a non-electrogenic enzyme (Peltier et al. 2016), was found in Symbiodiniaceae clade A (genus Symbiodinium) (Aihara et al. 2016). Because NDH-2 is a non-electrogenic enzyme, recent evidence suggests it is primarily involved in PSI-CEF rather than in chlororespiration (Peltier et al. 2016; Aihara et al. 2016). The second type of enzyme, PTOX (plastid terminal oxidase) takes up electrons from plastoquinol (PQH2) to reduce oxygen (Nawrocki et al. 2015). Two types of PTOX (PTOX 1 and PTOX 2) have been found in Prasinophyceae, Chlorophyceae, Bacillariophyceae and Rhodophyta. To our knowledge, no information is yet available concerning Symbiodiniaceae. However, Roberty et al. (2014) identified a PTOX-related sequence in the EST database of Symbiodiniaceae belonging to clade A (genus Symbiodinium) but their results suggest low PTOX activity. Houille-Vernes et al. (2011) and Nawrocki et al. (2019) showed that PTOX2 is the main oxidase involved in chlororespiration in Chlamydomonas reinhardtii and its absence from K.O. PTOX2 mutant led to the same type of fluorescence behavior as we observed in Porites astreoides. The reduced efficiency of PTOX 1 electron flows for oxidized PQH2 compared to those of PTOX2 entail a higher reduction of the PQ pool and a lower value $F_{\mathrm{v}} / F_{\mathrm{m}}$ in the dark (Houille-Vernes et al. 2011; Nawrocki et al. 2019). Even if it is not yet possible to draw a parallel between studies performed on C. reinhardtii and our results, it is possible that the singular behavior of Porites astreoides we observed is due to a difference in PTOX function and/or activity between species of Symbiodiniaceae.

Almost all current studies on Symbiodiniaceae photobiology deal with photosynthesis and the regulation of photoacclimation mechanisms under high light intensity (Suggett et al. 2008; Roberty et al. 2014, 2015; Hill et al. 2012; Slavov et al. 2016). Beyond linear electron flow (LEF) and standard non-phototochemical quenching acclimation, AEF has been described in many articles and the absence of state transition regulation has been pointed out in Symbiodiniaceae (Hill et al. 2012; Kanazawa et al. 2014; Roberty et al. 2014, 2015). Like Reynolds et al. (2008), we found positive PQ-reduction SIP responses in the three species of the genus Porites we tested here. Reynolds et al. (2008) first attributed this regulation to PSICEF and chlororespiration, then Roberty et al. (2014) showed that the "Water-Water Cycle" (Mehler reaction) was the main AEF in Symbiodiniaceae lineages ITS2 type A1, B1, F1, enabling photoreduction of oxygen by PSI under high light intensity and moderate temperatures 
(Roberty et al. 2015). Therefore, the chlororespiration pathway was only proposed as a weak mechanism in the dissipation of energy during the light phase (Roberty et al. 2015).

At this stage, our study does not enable us to characterize the chlororespiration-like mechanism precisely, however, it does allow us to ask an important question: how does Porites astreoides benefit from a potential high reduction power during the night? Several hypotheses are possible but will require further experiments with different data than the ones obtained using PAM fluorometry.

In addition, the role of chlororespiration is still the subject of debate [for a review, see Nawrocki et al. (2015), and Peltier et al. (2016)]. Chlororespiration has been linked to nitrogen depletion in the green microalgae Chlamydomonas and Haematococcus (Peltier and Schmidt 1991; Scibilia et al. 2015; Saroussi et al. 2016, 2017), but there is no evidence of such a relationship in Symbiodiniaceae.

According to the literature, in the dark, chlororespiration maintains the redox poise of the photosynthetic electron transport chain thereby allowing more efficient photosynthesis upon re-illumination (Jones and Hoegh-Guldberg 2001; Nawrocki et al. 2019). This redox buffer could also play an indirect photoprotective role by promoting CEF and the ensuing photoprotective mechanisms (Nawrocki et al. 2015). Because our experiments were performed under natural light with a natural light cycle, we were not able to test this hypothesis, but future experiments using a controlled light cycle could provide relevant information regarding such a regulation.

Chlororespiration has also been shown to be one of the pathways involved in ROS-scavenging systems in chloroplasts that reduce the production of long-lived redox active compounds (Khorobrykh et al. 2020). Chlororespiration has been shown to be able to consume reactive oxygen species (ROS) and may reduce their production by reducing the $\mathrm{O}_{2}$ concentration in chloroplasts (Casano et al. 2000; Nixon 2000; Jones and Hoegh-Guldberg 2001, Beardall et al. 2003). ROS are mainly produced during the light phase but also in the dark, in the absence of photosynthetic activity (Tolleter et al. 2013; Diaz et al. 2016, Zhang et al. 2016). In coral, ROS are produced by the photosynthetic symbiont and the host, so diffusive transfer of ROS from one symbiotic partner to the other may occur (Nielsen et al. 2018; Zhang et al. 2016). In the presence of reduced $\mathrm{PQ}(\mathrm{PQH} 2)$, as we observed in our study on $P$. astreoides, $\mathrm{PQH} 2$ oxidation by a superoxide anion radical (a type of ROS) leads to the accumulation of $\mathrm{H}_{2} \mathrm{O}_{2}$ in the thylakoid membrane (Khorobrykh and Ivanov 2002; Khorobrykh et al. 2020). The mechanism of oxidation of $\mathrm{PQH} 2$ by a superoxide has not yet been directly explored in Symbiodiniaceae, but we found this to be consistent with observations of Zhang et al. (2016), who showed elevated production of $\mathrm{H}_{2} \mathrm{O}_{2}$ in $P$. astreoides in the dark. The chlororespiration-like mechanism we found could help reduce or balance the concentration of ROS produced by the symbiont and (or) originating in the host gastroderm.

The proposed antioxidant capacity of Porites astreoides in the dark phase will require further investigation considering the interactions between the photosynthetic symbiont and its host. However, it already allows us to explain the singular physiological mechanism found in Porites astreoides that probably enhances or at least contributes to its physiological resistance to current environmental changes. Our data favor the hypothesis that $P$. astreoides present peculiar physiological capabilities thanks to the symbiosis, which may enhance resilience among the Caribbean reef corals.

Acknowledgements This work was supported by funds from UMR BOREA, and the works done by P. Claquin and P.J. Lopez were cofunded by the Labex DRIIHM, French program "Investissements d'Avenir" (ANR-11-LABX-0010), managed by the ANR, and the OHM Littoral Caraibe.

\section{Compliance with ethical standards}

Conflict of interest On behalf of all authors, the corresponding author states that there is no conflict of interest.

\section{References}

Aihara Y, Takahashi S, Minagawa J (2016) Heat Induction of Cyclic Electron Flow around Photosystem I in the Symbiotic Dinoflagellate Symbiodinium. Plant Physiol 171:522-529

Alvarez-Filip L, Dulvy NK, Gill JA, Cote IM, Watkinson AR (2009) Flattening of Caribbean coral reefs: region-wide declines in architectural complexity. Proc Biol Sci 276:3019-3025

Beardall J, Quigg A, Raven JA (2003) Oxygen consumption: Photorespiration and chlororespiration. In: Larkum AWD, Douglas SE, Raven JA (eds) Photosynthesis in Algae, vol 14. Springer, Dordrecht, pp 157-181

Bennoun P (1994) Chlororespiration revisited - mitochondrial-plastid interactions in Chlamydomonas. Biochim Biophys Acta 1186:59-66

Bouchon C, Miller A, Bouchon-Navaro Y, Portillo P, Louis M (2004) Status of coral reefs in the French Caribbean islands and other islands of the Eastern Antilles. In: Wilkinson C (ed) Status of the coral reefs of the world. Australian institue of marine sciences, Australia, pp 493-507

Bouchon C, Portillo P, Bouchon-Navaro Y, Max L, Hoetjes P, Brathwaite A, Roach R, Oxenford H, O'farrell S, Day O (2008a) Status of coral reefs of the Lesser Antilles after the 2005 coral bleaching event. In: Wilkinson C, Souter D (eds) Status of Caribbean coral reefs after bleaching and hurricanes in 2005. Global coral reef monitoring network, and reef and rainforest research centre, Australia, pp 85-103

Bouchon C, Portillo P, Bouchon-Navaro Y, Louis M, Hoetjes P, De Meyer K, Armstrong H, Datadin V, Harding S, Mallela J, Parkinson R, Van Bochove J, Wynne S, Macrae D, Lirman D, Herlan J, Baker A, Collado L, Nimrod S, Mitchell J, Morrall C, Isaac C (2008b) Status of the coral reefs of the Lesser Antilles in 
2008: the French West Indies, the Netherlands Antilles, Anguilla, Antigua and Barbuda, Grenada, Trinidad and Tobago. In: Wilkinson C (ed) Status of the coral reefs of the world. Australian institute of marine sciences, Australia, pp 265-280

Bove CB, Ries JB, Davies SW, Westfield IT, Umbanhowar J, Castillo KD (2019) Common Caribbean corals exhibit highly variable responses to future acidification and warming. Proc Biol Sci 286. https://doi.org/10.1098/rspb.2018.2840

Byler KA, Carmi-Veal M, Fine M, Goulet TL (2013) Multiple symbiont acquisition strategies as an adaptive mechanism in the coral Stylophora pistillata. Plos One 8. https://doi.org/10.1371/ journal.pone.0059596

Casano LM, Zapata JM, Martin M, Sabater B (2000) Chlororespiration and poising of cyclic electron transport - Plastoquinone as electron transporter between thylakoid NADH dehydrogenase and peroxidase. J Biol Chem 275:942-948

Diaz JM, Hansel CM, Apprill A, Brighi C, Zhang T, Weber L, McNally S, Xun LP (2016) Species-specific control of external superoxide levels by the coral holobiont during a natural bleaching event. Nat Commun 7. https://doi.org/10.1038/ ncomms13801

Diaz-Almeyda EM, Prada C, Ohdera AH, Moran H, Civitello DJ, Iglesias-Prieto R, Carlo TA, LaJeunesse TC, Medina M (2017) Intraspecific and interspecific variation in thermotolerance and photoacclimation in Symbiodinium dinoflagellates. P Roy Soc B-Biol Sci 284. https://doi.org/10.1098/rspb.2017.1767

Enriquez S, Mendez ER, Hoegh-Guldberg O, Iglesias-Prieto R (2017) Key functional role of the optical properties of coral skeletons in coral ecology and evolution. P Roy Soc B Biol Sci 284. https:// doi.org/10.1098/rspb.2016.1667

Franklin LA, Seaton GGR, Lovelock CE, Larkum AWD (1996) Photoinhibition of photosynthesis on a coral reef. Plant Cell Environ 19:825-836

Gardner TA, Cote IM, Gill JA, Grant A, Watkinson AR (2003) Longterm region-wide declines in Caribbean corals. Science 301:958-960

Gardner SG, Raina JB, Ralph PJ, Petrou K (2017) Reactive oxygen species (ROS) and dimethylated sulphur compounds in coral explants under acute thermal stress. J Exp Biol 220:1787-1791

Genty B, Briantais JM, Baker NR (1989) The relationship between the quantum yield of photosynthetic electron-transport and quenching of chlorophyll fluorescence. Biochim Biophys Acta 990:87-92

Green DH, Edmunds PJ, Carpenter RC (2008) Increasing relative abundance of Porites astreoides on Caribbean reefs mediated by an overall decline in coral cover. Mar Ecol Prog Ser 359:1-10

Gregoire V, Schmacka F, Coffroth MA, Karsten U (2017) Photophysiological and thermal tolerance of various genotypes of the coral endosymbiont Symbiodinium sp (Dinophyceae). J Appl Phycol 29:1893-1905

Grottoli AG, Warner ME, Levas SJ, Aschaffenburg MD, Schoepf V, McGinley M, Baumann J, Matsui Y (2014) The cumulative impact of annual coral bleaching can turn some coral species winners into losers. Global Change Biol 20:3823-3833

Hauff B, Haslun JA, Strycha KB, Ostrom PH, Cervino JM (2016) Symbiont diversity of zooxanthellae (Symbiodinium spp.) in Porites astreoides and Montastraea cavernosa from a reciprocal transplant in the lower Florida Keys. Int J Biol 8:9-22

Hennige SJ, Suggett DJ, Warner ME, McDougall KE, Smith DJ (2009) Photobiology of Symbiodinium revisited: bio-physical and bio-optical signatures. Coral Reefs 28:179-195

Hill R, Ralph PJ (2008) Dark-induced reduction of the plastoquinone pool in zooxanthellae of scleractinian corals and implications for measurements of chlorophyll a fluorescence. Symbiosis $46: 45-56$
Hill R, Larkum AWD, Prasil O, Kramer DM, Szabo M, Kumar V, Ralph PJ (2012) Light-induced dissociation of antenna complexes in the symbionts of scleractinian corals correlates with sensitivity to coral bleaching. Coral Reefs 31:963-975

Houille-Vernes L, Rappaport F, Wollman F-A, Alric J, Johnson X (2011) Plastid terminal oxidase 2 (PTOX2) is the major oxidase involved in chlororespiration in Chlamydomonas. Proc Natl Acad Sci U S A 108:20820-20825

Iglesias-Prieto R, Beltran VH, LaJeunesse TC, Reyes-Bonilla H, Thome PE (2004) Different algal symbionts explain the vertical distribution of dominant reef corals in the eastern Pacific. P Roy Soc B Biol Sci 271:1757-1763

Jans F, Mignolet E, Houyoux P-A, Cardol P, Ghysels B, Cuine S, Cournac L, Peltier G, Remacle C, Franck F (2008) A type II $\mathrm{NAD}(\mathrm{P}) \mathrm{H}$ dehydrogenase mediates light-independent plastoquinone reduction in the chloroplast of Chlamydomonas. Proc Natl Acad Sci U S A 105:20546-20551

Japaud A (2017) Les coraux du genre Acropora sur les récifs des Petites Antilles: approches génétiques, écologiques et de conservation. $\mathrm{PhD}$ thesis, Université des Antilles, Pointe-à-Pitre, Guadeloupe, p 271

Javier Gonzalez-Barrios F, Alvarez-Filip L (2018) A framework for measuring coral species-specific contribution to reef functioning in the Caribbean. Ecol Indic 95:877-886

Jones RJ, Hoegh-Guldberg O (2001) Diurnal changes in the photochemical efficiency of the symbiotic dinoflagellates (Dinophyceae) of corals: photoprotection, photoinactivation and the relationship to coral bleaching. Plant Cell Environ 24:89-99

Kanazawa A, Blanchard GJ, Szabo M, Ralph PJ, Kramer DM (2014) The site of regulation of light capture in Symbiodinium: Does the peridinin-chlorophyll alpha-protein detach to regulate light capture? Biochim Biophys Acta 1837:1227-1234

Khorobrykh SA, Ivanov BN (2002) Oxygen reduction in a plastoquinone pool of isolated pea thylakoids. Photosynth Res 71:209-219

Khorobrykh S, Havurinne V, Mattila H, Tyystjärvi E (2020) Oxygen and ROS in photosynthesis. Plants 9:91. https://doi.org/10.3390/ plants 9010091

Kromkamp JC, Forster RM (2003) The use of variable fluorescence measurements in aquatic ecosystems: differences between multiple and single turnover measuring protocols and suggested terminology. Eur J Phycol 38:103-112

Krueger T, Becker S, Pontasch S, Dove S, Hoegh-Guldberg O, Leggat W, Fisher PL, Davy SK (2014) Antioxidant plasticity and thermal sensitivity in four types of symbiodinium sp. J Phycol 50:1035-1047

LaJeunesse TC (2002) Diversity and community structure of symbiotic dinoflagellates from Caribbean coral reefs. Mar Biol 141:387-400

LaJeunesse TC, Smith R, Walther M, Pinzon J, Pettay DT, McGinley M, Aschaffenburg M, Medina-Rosas P, Cupul-Magana AL, Lopez Perez A, Reyes-Bonilla H, Warner ME (2010) Hostsymbiont recombination versus natural selection in the response of coral-dinoflagellate symbioses to environmental disturbance. P Roy Soc B Biol Sci 277:2925-2934

LaJeunesse TC, Parkinson JE, Gabrielson PW, Jeong HJ, Reimer JD, Voolstra CR, Santos SR (2018) Systematic revision of Symbiodiniaceae highlights the antiquity and diversity of coral endosymbionts. Curr Biol 28:2570-2580

Lesser MP (1996) Elevated temperatures and ultraviolet radiation cause oxidative stress and inhibit photosynthesis in symbiotic dinoflagellates. Limnol Oceanogr 41:271-283

Lesser MP (2006) Oxidative stress in marine environments: Biochemistry and physiological ecology. Annu Rev Physiol $68: 253-278$ 
Levas S, Schoepf V, Warner ME, Aschaffenburg M, Baumann J, Grottoli AG (2018) Long-term recovery of caribbean corals from bleaching. J Exp Mar Bio Ecol 506:124-134

Martin M, Sabater B (2010) Plastid ndh genes in plant evolution. Plant Physiol Bioch 48:636-645

McGinty ES, Pieczonka J, Mydlarz LD (2012) Variations in reactive oxygen release and antioxidant activity in multiple symbiodinium types in response to elevated temperature. Microb Ecol 64:1000-1007

Nawrocki WJ, Tourasse NJ, Taly A, Rappaport F, Wollman FA (2015) The plastid terminal oxidase: its elusive function points to multiple contributions to plastid physiology. Annual review of plant biology 66:49-74

Nawrocki WJ, Buchert F, Joliot P, Rappaport F, Bailleul B, Wollman F-A (2019) Chlororespiration controls growth under intermittent light. Plant Physiol 179:630-639

Nielsen DA, Petrou K, Gates RD (2018) Coral bleaching from a single cell perspective. Isme J 12:1558-1567

Nixon PJ (2000) Chlororespiration. P Roy Soc B Biol Sci 355:1541-1547

Peltier G, Schmidt GW (1991) Chlororespiration - an adaptation to nitrogen deficiency in chlamydomonas-reinhardtii. Proc Natl Acad Sci U S A 88:4791-4795

Peltier G, Aro EM, Shikanai T (2016) NDH-1 and NDH-2 plastoquinone peductases in oxygenic photosynthesis. Annual review of plant biology 67:55-80

Pochon X, Forsman ZH, Spalding HL, Padilla-Gamino JL, Smith CM, Gates RD (2015) Depth specialization in mesophotic corals (Leptoseris spp.) and associated algal symbionts in Hawaii. R Soc Open Sci 2. https://doi.org/10.1098/rsos.140351

Ragni M, Airs RL, Hennige SJ, Suggett DJ, Warner ME, Geider RJ (2010) PSII photoinhibition and photorepair in Symbiodinium (Pyrrhophyta) differs between thermally tolerant and sensitive phylotypes. Mar Ecol Prog Ser 406:57-70

Ralph PJ, Gademann R, Dennison WC (1998) In situ seagrass photosynthesis measured using a submersible, pulse-amplitude modulated fluorometer. Mar Biol 132:367-373

Rehman AU, Szabo M, Deak Z, Sass L, Larkum A, Ralph P, Vass I (2016) Symbiodinium sp cells produce light-induced intra- and extracellular singlet oxygen, which mediates photodamage of the photosynthetic apparatus and has the potential to interact with the animal host in coral symbiosis. New Phytol 212:472-484

Reynolds JM, Bruns BU, Fitt WK, Schmidt GW (2008) Enhanced photoprotection pathways in symbiotic dinoflagellates of shallow-water corals and other cnidarians. Proc Natl Acad Sci U S A 105:13674-13678

Roberty S, Bailleul B, Berne N, Franck F, Cardol P (2014) PSI Mehler reaction is the main alternative photosynthetic electron pathway in Symbiodinium sp., symbiotic dinoflagellates of cnidarians. New Phytol 204:81-91

Roberty S, Fransolet D, Cardol P, Plumier JC, Franck F (2015) Imbalance between oxygen photoreduction and antioxidant capacities in Symbiodinium cells exposed to combined heat and high light stress. Coral Reefs 34:1063-1073

Robison JD, Warner ME (2006) Differential impacts of photoacclimation and thermal stress on the photobiology of four different phylotypes of Symbiodinium (Pyrrhophyta). J Phycol 42:568-579

Romaine S, Tambutte E, Allemand D, Gattuso JP (1997) Photosynthesis, respiration and calcification of a zooxanthellate scleractinian coral under submerged and exposed conditions. Mar Biol 129:175-182

Rowan R, Knowlton N (1995) Intraspecific diversity and ecological zonation in coral algal symbiosis. Proc Natl Acad Sci U S A 92:2850-2853

Saroussi SI, Wittkopp TM, Grossman AR (2016) The type II NADPH dehydrogenase facilitates cyclic electron flow, energy-dependent quenching, and chlororespiratory metabolism during acclimation of Chlamydomonas reinhardtii to nitrogen deprivation. Plant Physiol 170:1975-1988

Saroussi S, Sanz-Luque E, Kim RG, Grossman AR (2017) Nutrient scavenging and energy management: acclimation responses in nitrogen and sulfur deprived Chlamydomonas. Curr Opin Plant Biol 39:114-122

Schoepf V, Grottoli AG, Levas SJ, Aschaffenburg MD, Baumann JH, Matsui Y, Warner ME (2015) Annual coral bleaching and the long-term recovery capacity of coral. Proc. R. Soc. B 282:20151887. https://doi.org/10.1098/rspb.2015.1887

Scibilia L, Girolomoni L, Berteotti S, Alboresi A, Ballottari M (2015) Photosynthetic response to nitrogen starvation and high light in Haematococcus pluvialis. Algal Res 12:170-181

Serrano XM, Baums IB, Smith TB, Jones RJ, Shearer TL, Baker AC (2016) Long distance dispersal and vertical gene flow in the Caribbean brooding coral Porites astreoides. Sci Rep 6. https:// doi.org/10.1038/srep21619

Slavov C, Schrameyer V, Reus M, Ralph PJ, Hill R, Buchel C, Larkum AWD, Holzwarth AR (2016) "Super-quenching" state protects Symbiodinium from thermal stress - Implications for coral bleaching. Biochim Biophys Acta Bioenerg 1857:840-847

Suggett DJ, Warner ME, Smith DJ, Davey P, Hennige S, Baker NR (2008) Photosynthesis and production of hydrogen peroxide by Symbiodinium (Pyrrhophyta) phylotypes with different thermal tolerances. J Phycol 44:948-956

Takahashi S, Whitney SM, Badger MR (2009) Different thermal sensitivity of the repair of photodamaged photosynthetic machinery in cultured Symbiodinium species. Proc Natl Acad Sci U S A 106:3237-3242

Tolleter D, Seneca FO, DeNofrio JC, Krediet CJ, Palumbi SR, Pringle JR, Grossman AR (2013) Coral bleaching independent of photosynthetic activity. Curr Biol 23:1782-1786

Wangpraseurt D, Lichtenberg M, Jacques SL, Larkum AWD, Kuehl M (2019) Optical Properties of Corals Distort Variable Chlorophyll Fluorescence Measurements. Plant Physiol 179:1608-1619

Warner ME, LaJeunesse TC, Robison JD, Thur RM (2006) The ecological distribution and comparative photobiology of symbiotic dinoflagellates from reef corals in Belize: Potential implications for coral bleaching. Limnol Oceanogr 51:1887-1897

Wooldridge SA, Done TJ (2009) Improved water quality can ameliorate effects of climate change on corals. Ecol Appl 19:1492-1499

Zhang T, Diaz JM, Brighi C, Parsons RJ, McNally S, Apprill A, Hansel CM (2016) Dark production of extracellular superoxide by the coral Porites astreoides and representative symbionts. Front Mar Sci 3. https://doi.org/10.3389/fmars.2016.00232

Publisher's Note Springer Nature remains neutral with regard to jurisdictional claims in published maps and institutional affiliations. 